\title{
Teaching Video NeuroImage: New STUB1 Variant Causes Chorea, Tremor, Dystonia, Myoclonus, Ataxia, Depression, Cognitive Impairment, Epilepsy, and Superficial Siderosis
}

Carsten Saft, MD, Sabine Skodda, MD, Huu Phuc Nguyen, MD, Joohyun Park, MD, and Tobias B. Haack, MD Neurology ${ }^{\circledR}$ 2021;97:e1749-e1750. doi:10.1212/WNL.0000000000012264

Figure Imaging Results
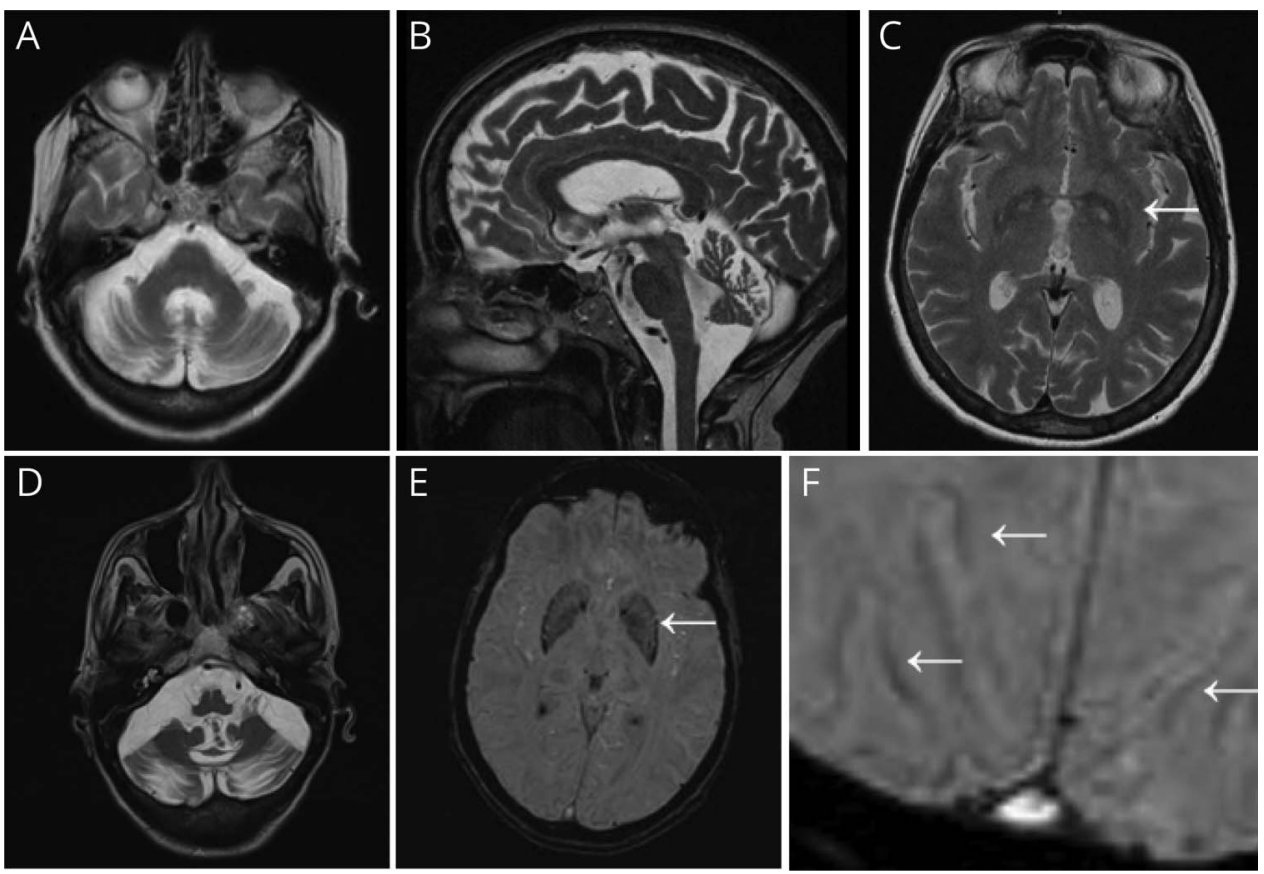

(A-C) T2-weighted MRI of the grandmother shows cerebellar atrophy (A, B) and basal ganglia hypointensity (with no correlate in cerebral CT; C; see arrow). (D-F) T2-weighted and susceptibility-weighted imaging(SWI)-weighted MRI of the mother shows cerebellar atrophy (D) and basal ganglia SWI artifacts ( $E$; see arrow) and cortical SWI artifacts highly suggestive of superficial siderosis (F; see arrows).

We present a family with a wide range of movement disorders carrying a new heterozygous splice variant in STUB1 (NM_005861:c.787-2_787del), probably causing skipping of exon 7, as relevant differential diagnosis to Huntington disease. ${ }^{1,2}$ The grandmother and mother (improved with olanzapine) presented with chorea, dystonia (also platysma), head tremor, orofacial dyskinesias (prior to neuroleptics), saccadic eye movements, ataxia with cerebellar atrophy (Figure), depression, cachexia, and cognitive impairment. The grandmother had epilepsy and the mother had superficial siderosis (Figure). The son presented with depression, leftsided myoclonus and ataxia, and tremor resembling essential tremor, which began in childhood, without alcohol sensitivity. STUB1 mutation in this family caused chorea, tremor, dystonia,

\section{Correspondence}

Dr. Saft

carsten.saft@

ruhr-uni-bochum.de

\section{MORE ONLINE}

\section{Video}

\section{Teaching slides}

links.lww.com/WNL/

B434

From the Department of Neurology (C.S.), Huntington-Centre NRW, St. Josef Hospital; Department of Neurology (S.S.), Knappschaftskrankenhaus; Department of Human Genetics (H.P.N.), Ruhr-University of Bochum; and Institute of Medical Genetics and Applied Genomics (J.P., T.B.H.), University of Tübingen, Germany.

Go to Neurology.org/N for full disclosures. Funding information and disclosures deemed relevant by the authors, if any, are provided at the end of the article. 
myoclonus, ataxia, depression, cognitive impairment, epilepsy, and superficial siderosis (Video 1).

\section{Study Funding}

The authors report no targeted funding.

\section{Disclosure}

The authors report no disclosures relevant to the manuscript. Go to Neurology.org/N for full disclosures.

Appendix Authors

\begin{tabular}{lll}
\hline Name & Location & Contribution \\
\hline $\begin{array}{l}\text { Carsten } \\
\text { Saft, MD }\end{array}$ & $\begin{array}{l}\text { Department of Neurology, } \\
\text { Huntington-Centre NRW, St. } \\
\text { Josef Hospital }\end{array}$ & $\begin{array}{l}\text { Drafting/revision of the } \\
\text { manuscript for content, } \\
\text { including medical writing for } \\
\text { content; Major role in the } \\
\text { acquisition of data; Study } \\
\text { concept or design; Analysis or } \\
\text { interpretation of data }\end{array}$ \\
\hline $\begin{array}{l}\text { Sabine } \\
\text { Skodda, } \\
\text { MD }\end{array}$ & Knappschaftskrankenhaus & $\begin{array}{l}\text { Drafting/revision of the } \\
\text { manuscript for content, } \\
\text { including medical writing for } \\
\text { content; Major role in the } \\
\text { acquisition of data }\end{array}$ \\
\hline
\end{tabular}

Appendix (continued)

\begin{tabular}{|c|c|c|}
\hline Name & Location & Contribution \\
\hline $\begin{array}{l}\text { Huu } \\
\text { Phuc } \\
\text { Nguyen, } \\
\text { MD }\end{array}$ & $\begin{array}{l}\text { Department of Human } \\
\text { Genetics, Ruhr-University of } \\
\text { Bochum }\end{array}$ & $\begin{array}{l}\text { Drafting/revision of the } \\
\text { manuscript for content, } \\
\text { including medical writing for } \\
\text { content; Analysis or } \\
\text { interpretation of data }\end{array}$ \\
\hline $\begin{array}{l}\text { Joohyun } \\
\text { Park, MD }\end{array}$ & $\begin{array}{l}\text { Institute of Medical Genetics } \\
\text { and Applied Genomics, } \\
\text { University of Tübingen, } \\
\text { Germany }\end{array}$ & $\begin{array}{l}\text { Drafting/revision of the } \\
\text { manuscript for content, } \\
\text { including medical writing for } \\
\text { content; Major role in the } \\
\text { acquisition of data; Analysis or } \\
\text { interpretation of data }\end{array}$ \\
\hline $\begin{array}{l}\text { Tobias B. } \\
\text { Haack, } \\
\text { MD }\end{array}$ & $\begin{array}{l}\text { Institute of Medical Genetics } \\
\text { and Applied Genomics, } \\
\text { University of Tübingen, } \\
\text { Germany }\end{array}$ & $\begin{array}{l}\text { Drafting/revision of the } \\
\text { manuscript for content, } \\
\text { including medical writing for } \\
\text { content; Major role in the } \\
\text { acquisition of data; Analysis or } \\
\text { interpretation of data }\end{array}$ \\
\hline
\end{tabular}

\section{References}

1. Roux T, Barbier M, Papin M, et al; SPATAX network. Clinical, neuropathological, and genetic characterization of STUB1 variants in cerebellar ataxias: a frequent cause of predominant cognitive impairment. Genet Med. 2020;22(11):1851-1862.

2. De Michele G, Galatolo D, Barghigiani M, et al. Spinocerebellar ataxia type 48: last but not least. Neurol Sci. 2020;41(9):2423-2432. 


\section{Neurology}

Teaching Video NeuroImage: New STUB1 Variant Causes Chorea, Tremor, Dystonia, Myoclonus, Ataxia, Depression, Cognitive Impairment, Epilepsy, and Superficial Siderosis

Carsten Saft, Sabine Skodda, Huu Phuc Nguyen, et al.

Neurology 2021;97;e1749-e1750 Published Online before print May 26, 2021

DOI 10.1212/WNL.0000000000012264

This information is current as of May 26, 2021

\section{Updated Information \&} Services

References

Subspecialty Collections

Permissions \& Licensing

Reprints including high resolution figures, can be found at: http://n.neurology.org/content/97/17/e1749.full

This article cites 2 articles, 0 of which you can access for free at: http://n.neurology.org/content/97/17/e1749.full\#ref-list-1

This article, along with others on similar topics, appears in the following collection(s):

\section{Chorea}

http://n.neurology.org/cgi/collection/chorea

Huntington's disease

http://n.neurology.org/cgi/collection/huntingtons_disease

Myoclonus

http://n.neurology.org/cgi/collection/myoclonus

Spinocerebellar ataxia

http://n.neurology.org/cgi/collection/spinocerebellar_ataxia

Tremor

http://n.neurology.org/cgi/collection/tremor

Information about reproducing this article in parts (figures,tables) or in its entirety can be found online at:

http://www.neurology.org/about/about_the_journal\#permissions

Information about ordering reprints can be found online:

http://n.neurology.org/subscribers/advertise

Neurology ${ }^{\circledR}$ is the official journal of the American Academy of Neurology. Published continuously since 1951, it is now a weekly with 48 issues per year. Copyright @ 2021 American Academy of Neurology. All rights reserved. Print ISSN: 0028-3878. Online ISSN: 1526-632X.

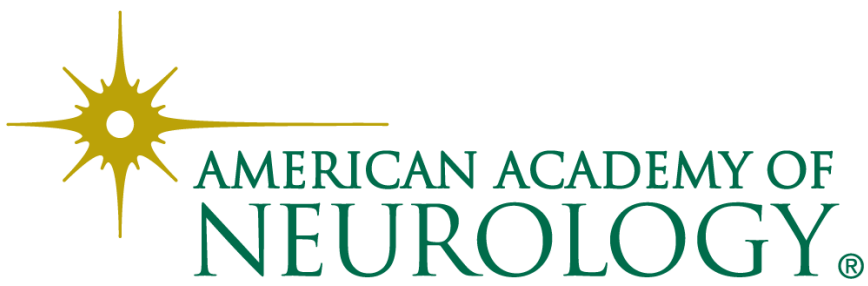

